\title{
Possible Effects of Location and Handling on Some Fungi Associated with Rotting Citrullus lanatus Thunb. (Watermelon)
}

\author{
Ayodele Adegboyega Sobowale (1) \\ Department of Botany, University of Ibadan, Ibadan, Nigeria \\ Email: delesobowale@yahoo.com
}

How to cite this paper: Sobowale, A.A. (2019) Possible Effects of Location and Handling on Some Fungi Associated with Rotting Citrullus lanatus Thunb. (Watermelon). American Journal of Plant Sciences, 10, 1061-1068.

https://doi.org/10.4236/ajps.2019.106077

Received: May 7, 2019

Accepted: June 25, 2019

Published: June 28, 2019

Copyright () 2019 by author(s) and Scientific Research Publishing Inc. This work is licensed under the Creative Commons Attribution International License (CC BY 4.0).

http://creativecommons.org/licenses/by/4.0/

\begin{abstract}
An experiment was conducted to examine probable impact of location and handling on the fungi commonly associated with rotting watermelon (Citrullus lanatus). The rotting watermelon samples were obtained from two vendors each from five different markets (Bodija, Sango, Mokola, Eleyele, Agbowo and Ojoo) in Ibadan, Oyo state. They were placed in different sterile sample bags which were labeled appropriately before bringing them to the Pathology Laboratory, Department of Botany, University of Ibadan. Isolation of fungi from the rotting samples was carried out using pour plate method on acidified Potato Dextrose Agar (APDA). Pathogenicity test was also conducted for the isolated fungi. All experiments were done in duplicates and all plates were incubated at $25^{\circ} \mathrm{C} \pm 2^{\circ} \mathrm{C}$ for 7 days. Pure cultures were obtained and identified and each isolated fungus was recorded as 1 which means present and 0 which means absent. The data obtained were analyzed using SAS version 9.3 at $\mathrm{p} \leq 0.05$. A total of three fungi were isolated viz., Aspergillus flavus, Saccharomyces cerevisae and Aspergillus niger. Occurrence of A. niger and $A$. flavus in samples obtained from Bodija, Mokola, Sango and Ojoo markets were significantly $(\mathrm{P} \leq 0.05)$ higher than those from the other two markets. Occurrence of $S$. cerevisae in samples obtained from Bodija and Mokola markets were significantly $(\mathrm{P} \leq 0.05)$ higher than those from the other three markets. Location had significant impact on the occurrence of isolated fungi in the rotting watermelons. However, handling by vendors had no significant impact on occurrence of the isolated fungi. Vendors and consumers are advised to be mindful of place of purchase and to also maintain good general hygiene before consumption.
\end{abstract}

\section{Keywords}

Watermelon, A. flavus, S. cerevisae, A. niger, Locations, Vendors 


\section{Introduction}

Citrullus lanatus (watermelon) is a tropical fruit which can be found in most parts of Africa, Asia, United States and Russia [1]. According to [2], they originated in Africa and had been in cultivation for more than 4000 years in the drier parts of the continent and throughout India and parts of Asia. The plant is well adapted to tropical and subtropical regions where cultivation is high. Its existence started in the dry regions of southern Africa and it is produced all over the world particularly in the semi-arid regions [3]. They are among the most widely grown vegetable crops in the warmer parts of the world [3] [4] [5].

In Nigeria, the largest production of watermelon (Citrullus lanatus Thunb family cucurbitaceae) comes from the Northern part in Nigeria [6]. They are grown and are quite popular in the Northern part of Nigeria especially in the central and north-eastern part [7].

It is highly nutritious and low in calories [8] and can be used as an appetizer or snack [9]. It's nutritional and medicinal values have been well documented [7]. Apart from being a source of some vitamins, it is known to be popular for its thirst quenching ability in Africa during water shortage [4] [10] [11]. It is a natural and rich source of phytochemical compounds which are believed to be beneficial for human health and well-being [12]. It is known to play a role in the protection of prostrate and oral cancer [7]. The seeds are used in the treatment of hypertension, diabetes, diarrhea and gonorrhea [13]. It is a fruit that is a good source of potassium which is an important component of cell and body fluids that helps in controlling heart rate and blood pressure thereby preventing stroke and coronary heart diseases [14]. It contains high level of antioxidant which decreases the risk of kidney stone and bone loss due to old age [15].

However, apart from insect infestation, watermelon is susceptible to several plant pathogens (fungi, bacteria, nematodes and viruses) which attack the roots, foliage and fruit thereby limiting their marketability and the yield of the growers [16] [17]. The aim of the study therefore is to examine the probable effect of location and handling on fungi associated with rotting watermelon.

\section{Methodology}

\subsection{Collection of Samples}

Rotting watermelon samples were collected from 2 vendors each from 5 different markets in Ibadan, Oyo state viz., Sango, Bodija, Ojoo, Eleyele, Mokola. All the samples were labelled appropriately and taken to the Pathology Laboratory, Department of Botany, University of Ibadan.

\subsection{Isolation and Identification of Fungi from Rotting Watermelon}

Small portions were excised from different parts of the rotting watermelon using a sterile knife and cultured on Petri Plates of acidified Potato Dextrose Agar (APDA). The Petri Plates were incubated at room temperature $\left(27^{\circ} \mathrm{C}\right)$ for 5 days 
when they were observed daily for fungal growth. All experiments were done in duplicates and each isolated fungus was later sub-cultured unto sterile Plates of APDA to obtain pure cultures which were later identified. Pathogenicity test was later carried out for the isolated fungi.

\subsection{Data Collection and Statistical Analysis}

The isolation of each fungus from all the samples was recorded as either present (1) or absent (0). The data collected were subjected to analysis of variance (ANOVA) using the Generalized Linear Model option of SAS 9.3 version.

\section{Results}

Three fungi were isolated from the rotting Citrullus lanatus (watermelon) fruits viz., Aspergillus flavus (Plate 1), Aspergillus niger (Plate 2), and Saccharomyces cerevisae.

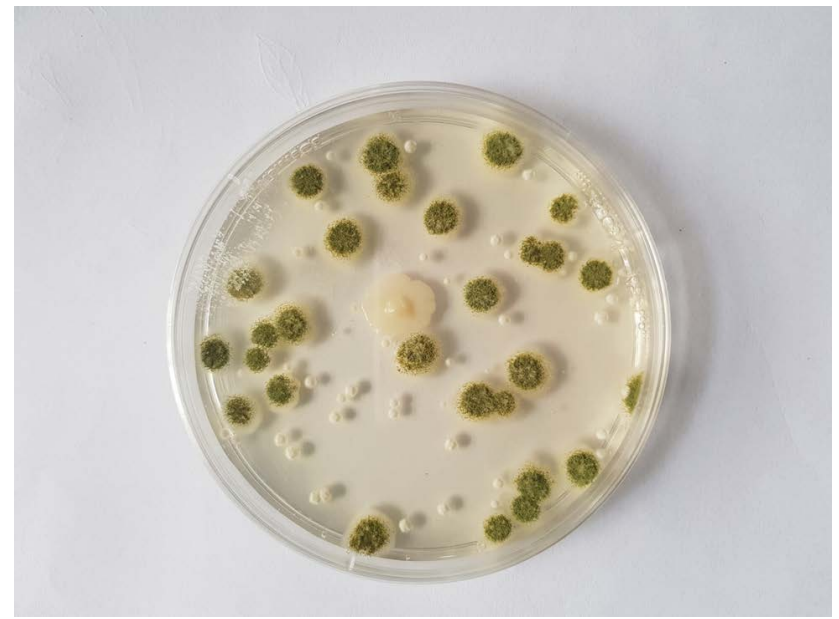

Plate 1. Aspergillus flavus from rotting watermelon obtained from Bodija, Mokola and Sango market in Ibadan.

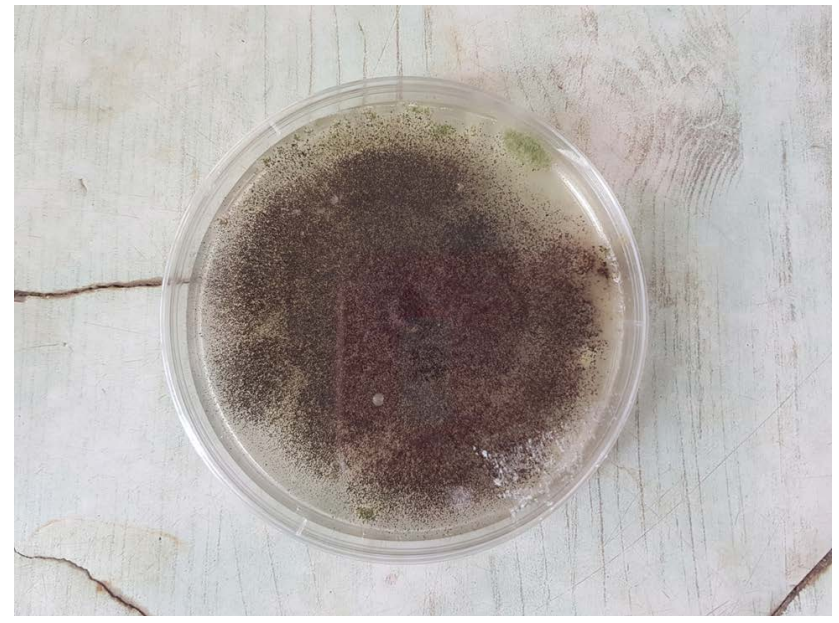

Plate 2. Aspergillus niger from rotting watermelon obtained from Bodija, Mokola and Ojoo markets in Ibadan. 
Table 1 shows the means comparison of the isolated fungi in the watermelon obtained from the five different markets in Ibadan. The incidence of Aspergillus niger in rotting Citrullus lanatus obtained from Bodija, Mokola and Ojoo markets was significantly ( $\mathrm{p} \leq 0.05$ ) higher than those in Citrullus lanatus obtained from the other two markets. The incidence of Aspergillus flavus in rotting Citrullus lanatus obtained from Bodija, Sango and Mokola markets was significantly ( $\mathrm{p} \leq$ 0.05) higher than those in Citrullus lanatus obtained from the other two markets. However the incidence of Saccharomyces cerevisae in rotting Citrullus lanatus obtained from Bodija and Mokola markets was significantly ( $\mathrm{p} \leq 0.05$ ) higher than those in Citrullus lanatus obtained from the other markets.

Table 2 shows the overall means comparisons of incidence of the isolated fungi in Citrullus lanatus obtained from the five markets in Ibadan. Generally, the incidences of all the isolated fungi in the rotting Citrullus lanatus obtained from Bodija and Mokola markets were significantly $(\mathrm{p} \leq 0.05)$ higher than those in Citrullus lanatus obtained from Sango and Ojoo markets. The incidences of all the isolated fungi in the rotting Citrullus lanatus obtained from Sango and Ojoo markets were significantly $(\mathrm{p} \leq 0.05)$ higher than those in Citrullus lanatus obtained from Eleyele market.

Table 3 shows the means comparison of the isolated fungi in Citrullus lanatus obtained from the two vendors in each of the markets. The incidences of the three isolated fungi in the rotting Citrullus lanatus obtained from the two vendors in each of the markets were not significantly $(\mathrm{p} \leq 0.05)$ different. Similar result was obtained in Table 4 where overall incidence of the isolated fungi in Citrullus lanatus from the two vendors in each of the markets were compared. The ANOVA table for incidence of the isolated fungi in Citrullus lanatus obtained from the five markets is given in Table 5. The F-values $(p>0.0001)$ for model and location were all highly significant for the three isolated fungi.

Table 1. Means comparison of the isolated fungi in Citrullus lanatus obtained from five different markets in Ibadan, Nigeria.

\begin{tabular}{cccc}
\hline & $\begin{array}{c}\text { Aspergillus } \\
\text { niger }\end{array}$ & $\begin{array}{c}\text { Aspergillus } \\
\text { flavus }\end{array}$ & $\begin{array}{c}\text { Saccharomyces } \\
\text { cerevisae }\end{array}$ \\
\hline Location & Means & Means & Means \\
Bodija & $1.000 \mathrm{a}$ & $1.000 \mathrm{a}$ & $1.000 \mathrm{a}$ \\
Sango & $0.000 \mathrm{~b}$ & $1.000 \mathrm{a}$ & $0.000 \mathrm{~b}$ \\
Mokola & $1.000 \mathrm{a}$ & $1.000 \mathrm{a}$ & $1.000 \mathrm{a}$ \\
Eleyele & $0.000 \mathrm{~b}$ & $0.000 \mathrm{~b}$ & $0.000 \mathrm{~b}$ \\
Ojo & $1.000 \mathrm{a}$ & $0.000 \mathrm{~b}$ & $0.000 \mathrm{~b}$ \\
$\mathrm{R}^{2}$ & 0.6 & 0.6 & 0.4 \\
\hline
\end{tabular}

Means with the same letters are not significantly different $(\mathrm{p} \leq 0.05)$. 
Table 2. Overall means comparisons of incidence of the isolated fungi in Citrullus lanatus obtained from the five markets in Ibadan, Nigeria.

\begin{tabular}{cl}
\hline Locations & Means \\
\hline Bodija & $1.0000 \mathrm{a}$ \\
Sango & $0.3333 \mathrm{~b}$ \\
Mokola & $1.0000 \mathrm{a}$ \\
Eleyele & $0.0000 \mathrm{c}$ \\
Ojoo & $0.3333 \mathrm{~b}$ \\
\hline
\end{tabular}

Means with the same letters are not significantly different $(\mathrm{p} \leq 0.05)$.

Table 3. Means comparison of the isolated fungi in Citrullus lanatus obtained from the two vendors in each of the markets.

\begin{tabular}{cccc}
\hline & $\begin{array}{c}\text { Aspergillus } \\
\text { niger }\end{array}$ & $\begin{array}{c}\text { Aspergillus } \\
\text { flavus }\end{array}$ & $\begin{array}{c}\text { Saccharomyces } \\
\text { cerevisae }\end{array}$ \\
\hline Vendor & Means & Means & Means \\
1 & $0.600 \mathrm{a}$ & $0.600 \mathrm{a}$ & $0.400 \mathrm{a}$ \\
2 & $0.600 \mathrm{a}$ & $0.600 \mathrm{a}$ & $0.400 \mathrm{a}$ \\
\hline
\end{tabular}

Means with the same letters are not significantly different $(\mathrm{p} \leq 0.05)$.

Table 4. Overall means comparisons of incidence of the isolated fungi in Citrullus lanatus obtained from the two vendors in each market.

\begin{tabular}{ccc}
\hline Vendor & Means \\
\hline 1 & $0.5333 \mathrm{a}$ \\
2 & $0.5333 \mathrm{a}$ \\
\hline
\end{tabular}

Means with the same letters are not significantly different $(\mathrm{p} \leq 0.05)$.

Table 5. ANOVA table for incidence of the isolated fungi in Citrullus lanatus obtained from five markets in Ibadan, Nigeria.

\begin{tabular}{ccccccc}
\hline & \multicolumn{2}{c}{$\begin{array}{c}\text { Aspergillus } \\
\text { niger }\end{array}$} & \multicolumn{2}{c}{$\begin{array}{c}\text { Aspergillus } \\
\text { flavus }\end{array}$} & \multicolumn{2}{c}{$\begin{array}{c}\text { Saccharomyces } \\
\text { cerevisae. }\end{array}$} \\
\hline Source of variation & MS & $\mathrm{P}<\mathrm{F}$ & $\mathrm{MS}$ & $\mathrm{P}<\mathrm{F}$ & $\mathrm{MS}$ & $\mathrm{P}<\mathrm{F}$ \\
Model & 0.80 & $0.0001^{*}$ & 0.80 & $0.0001^{*}$ & 0.80 & $0.0001^{*}$ \\
Location & 1.20 & $0.0001^{*}$ & 1.20 & $0.0001^{*}$ & 1.20 & $0.0001^{*}$ \\
Vendor & - & - & - & - & - & -
\end{tabular}

*Significant.

\section{Discussion}

The significant occurrence of all the isolated fungi in watermelon obtained from one market compared to the other might be as a result of infection from the fields where the watermelon were harvested. Postharvest pathogens which come as a result of infection from the field is a common occurrence. S. cerevisae are 
known to be saprophytes growing on any substrates containing sugar [18] and they possibly originate from the field and are transported on surfaces of fruits to fruit stalls and stores. Saccharomyces cerevisae has also been reported to be associated with spoilage of tomato, pepper and orange [19] [20] [21] [22]. However, Nwachukwu et al. [23] [24] [25] [26] found $S$. cerevisiae as contaminants of fresh sliced ready-to-eat watermelon fruits sold on the streets of some cities in Nigeria.

A. niger and A. flavus has been isolated from watermelon in storage and deterioration of fruits by $A$. niger has been reported in watermelon by some researchers including [27] [28]. It has also been reported in other fruits by other researchers such as [29] [30] [31] [32].

However, the significant occurrence of the three fungi in watermelon obtained from Bodija and Mokola compared to other markets is suggestive. This might be due to the fact that the different locations of the markets play a part in determining occurrence of fungi in the watermelon. It is suggesting a strong association between these fungi and the two markets (Bodija and Mokola). It might as well be indicative of the hygiene conditions of these two markets. This is also corroborated by the significant occurrence of the isolated fungi in watermelon from Sango and Ojoo markets compared to those from Eleyele market. It might mean that fungal occurrence on watermelon might not be only as a result of infection from the field, especially if the fruits from the markets are not from a common farm. However results obtained with the vendors suggested that individual vendors of the fruit might not play a part in determining occurrence of fungi in the fruit. The significant $F$ value ( $p>0.0001$ ) for model for the three isolated fungi shows appropriateness of the model. It shows the goodness of fit of the model. The significant $F$ values ( $p>0.0001)$ for location for the three isolated fungi confirm the significant $F$ values for the models. It shows that the location where the watermelon is purchased most likely determines occurrence of the fungi in the fruit. It suggests a strong association of these fungi with Mokola and Bodija markets. The significant F values $(p>0.0001)$ for location also confirm the results obtained with the isolated fungi in watermelon from the different markets.

\section{Conclusion}

Saccharomyces cerevisae are known to be saprophytes growing on any substrates containing sugar and they possibly originate from the field and are transported on surfaces of fruits to fruit stalls and stores. Vendors and consumers alike are advised to be mindful of where they purchase their fruits. Consumers particularly need to maintain a high level of hygiene, especially after purchase before consumption.

\section{Conflicts of Interest}

The author declares no conflicts of interest regarding the publication of this paper. 


\section{References}

[1] Mogotlane, E.A., Mokwala, P.W. and Mangena, P. (2018) Comparative Analysis of the Chemical Compositions of Indigenous Watermelon (Citrullus lanatus) Seeds from Two Districts in Limpopo Province, South Africa. African Journal of Biotechnology, 17, 1001-1006. https://doi.org/10.5897/AJB2018.16552

[2] Cobley, L.S. and Steele, W.M. (1976) An Introduction to the Botany of Tropical Crops. Longman Group Ltd., London.

[3] Wehner, T.C., Shetty, N.V. and Elmestron, G.W. (2001) In: D.N. Maynard (ed.). Watermelons Characteristics, Production, and Marketing 160 Afr. J. Plant Sci.

[4] Maynard, D.N. (2001) An Introduction to the Watermelon. In: Watermelons: Characteristics, Production, and Marketing, ASHS Press, Alexandria, VA, 9-20.

[5] Wehner, T.C. (2008) Watermelon. In: Prohens, J. and Nuez, F., Eds., Vegetables I. Handbook of Plant Breeding, Springer, New York, 381-418.

https://doi.org/10.1007/978-0-387-30443-4_12

[6] IITA (2007) Watermelon Production in Nigeria. A Practical Guide, 3-15.

[7] Gwana, A.M., Bako, M.M., Bagudu, B.Y., Sadiq, A.B. and Abdullah, I.M.M. (2014) Determinations of Phytochemical, Vitamin, Mineral and Proximate Compositions of Varieties of Watermelon Seeds Cultivated in Borno State, North-Eastern Nigeria. International Journal of Nutrition and Food Sciences, 3, 238-245.

[8] Okonmah, L.U., Agbogidi, O.M. and Nwagu, O.K. (2011) Evaluation of Four Varieties of Watermelon (Citrullus lanatus Thumb) in Asaba Agro-Ecological Environment. International Journal of Advanced Biological Research, 1, 126-130.

[9] Şalk, A., Arin, L., Deveci, M. and Polat, S. (2008) Özel Sebzecilik (In Turkish).

[10] Ensminger, A.H., Esminger, M.E., Konlande, J.E. and Robson, J.R.K. (1986) Food for Health: A Nutrition Encyclopedia. Pegus Press: Clovis, CA, 1061-1072.

[11] Levetin, E.K. and Mrnahoii, C. (2003) Plants and Society. 3rd Edition, McGraw Hill, New York.

[12] Abu-Reidah, I.M., Arraez-Roman, D., Carretero, A.S. and Fernandez-Gutierrez, A. (2013) Profiling of Phenolic and Other Polar Constituents from Hydro-Methanolic Extract of Watermelon (Citrullus lanatus) by Means of Accurate-Mass Spectrometry (HPLC-ESI-QTOF-MS). Food Research International, 51, 354-362. https://doi.org/10.1016/j.foodres.2012.12.033

[13] Erhirhie, E.O. and Ekene, N.E. (2013) Medical Values on Watermelon (Citrullus lanatus). Pharmacological Review. International Journal of Research in Pharmaceutical and Biomedical Sciences, 4, 1205-1312.

[14] Le, J., Chuan, J.D., Andy, H.L. and Colin, W.E. (2005) Do Dietary Lycopene and Other Carotenoids Protect against Prostate Cancer? International Journal of Cancer, 113, 1010-1014. https://doi.org/10.1002/ijc.20667

[15] Olayinka, B.U. and Etejere, E.O. (2018) Proximate and Chemical Compositions of Watermelon (Citrullus lanatus Thunb.) Matsum and Nakai cv Red and Cucumber (Cucumis sativus L. cv Pipino). International Food Research Journal, 25, 1060-1066.

[16] Sanders, D.C. (2001) Vegetable Crop Guidelines for the Southeastern U.S. North Carolina Cooperative Extension Service.

[17] Bulajić, A., Krstić, B. and Ivanović, M. (2008) Bolesti lubenice i mere suzbijanja. Biljni lekar, 36, 426-435.

[18] Singh, D. and Sharma, R.R. (2007) Postharvest Diseases of Fruit and Vegetables and Their Management. In: Prasad, D., Ed., Sustainable Pest Management, Daya Publishing House, New Delhi, India. 
[19] Mbajiuka, S.C. and Enya, E. (2014) Isolation of Microorganisms Associated with Deterioration of Tomato (Lycopersicon esculentum) and Pawpaw (Carica papaya) Fruits. International Journal of Current Microbiology and Applied Sciences, 3, 501-512.

[20] Agbabiaka, T.O., Saliu, B.K., Sule, I.O., Oyeyiola, G.P. and Odedina, G.F. (2015) Microbial Deterioration of Tomato Fruit (Lycopersicon esculentum) Sold in Three Popular Markets in Ilorin, Kwara State, Nigeria. Fountain Journal of Natural and Applied Sciences, 4, 10-18.

[21] Ibrahim, M. and Sada, M.D. (2015) Yeasts Associated with Spoilage of Some Selected Fruits in Sokoto Metropolis. http://scienceq.org/Journals/JALS.php

[22] Oviasogie, F.E., Ogofure, A.G., Beshiru, A., Ode, J.N. and Omeje, F.I. (2015) Assessment of Fungal Pathogens Associated with Orange Spoilage. African Journal of Microbiology Research, 9, 1758-1763. https://doi.org/10.5897/AJMR2014.7246

[23] Nwachukwu, E., Ezeama, C.F. and Ezeanya, B.N. (2008) Microbiology of Polyethylene-Packaged Sliced Watermelon (Citrullus lanatus) Sold by Street Vendors in Nigeria. African Journal of Microbiology Research, 2, 192-195.

[24] Nwachukwu, E. and Osuocha, H.U. (2014) Microbiological Assessment of Ready-toEat Sliced Pawpaw (Carica papaya) and Watermelon (Citrullus lanatus) Vended in Umuahia, Nigeria. International Journal of Current Microbiology and Applied Sciences, 3, 910-916.

[25] Titilayo, A.F. and Salome, O.T. (2014) Microbiological Assessment of Sliced Watermelon (Citrullus lanatus) in Oyo, Nigeria. Natural science, 12, 88-91.

[26] Odebisi-Omokanye, M.B., Oke, M.A., Ahmed El-Imam, A.M., Ajijolakewu, A.K. and Salaudeen, B.I. (2015) Microbiological Quality and Safety of Pre-Cut Fruit Retailed in Ilorin, Kwara State, Nigeria. Fountain Journal of Natural and Applied Sciences, 4, 19-26.

[27] Udoh, I.P., Eleazar, C.I., Ogeneh, B.O. and Ohanu, M.E. (2015) Studies on Fungi Responsible for the Spoilage/Deterioration of Some Edible Fruits and Vegetables. Advances in Microbiology, 5, 285-290.

[28] Samuel, T.O., Egwuatu, T.O.G. and Ebabhi, A.M. (2017) Microbial Contamination of Shea (vitellaria paradoxa G. Don) Butter from Local Markets in Southwestern and Edo State, Nigeria. Ife Journal of Science, 19, 333-339. https://doi.org/10.4314/ijs.v19i2.13

[29] Al-Hindi, R.R., Al-Najada, A.R. and Mohamed, S.A. (2011) Isolation and Identification of Some Fruit Spoilage Fungi: Screening of Plant Cell Wall Degrading Enzymes. African Journal of Microbiology Research, 5, 443-448.

[30] Tafinta, I.Y., Shehu, K., Abdulganiyyu, H., Rabe, A.M. and Usman, A. (2013) Isolation and Identification of Fungi Associated with the Spoilage of Sweet Orange ( $\mathrm{Ci}$ trus Sinensis) Fruits in Sokoto State. Nigerian Journal of Basic and Applied Sciences, 2, 193-196. https://doi.org/10.4314/njbas.v21i3.4

[31] Amadi, J.E., Nwaokike, P., Olahan, G.S. and Garuba, T. (2014) Isolation and Identification of Fungi Involved in the Post-Harvest Spoilage of Guava (Psidium guajava) in Awka Metropolis. International Journal of Engineering and Applied Sciences, 4 , 7-12.

[32] Aminu, F. and Ali, M. (2017) Isolation and Identification of Microorganisms Associated with Spoilage of Cabbage (Brassica oleracea) in Sabon-Gari Market Kano, Nigeria. International Journal of Advanced Science and Research, 3, 1-8. 